\title{
Case Report \\ Russell Body Gastroenteritis: An Aberrant Manifestation of Chronic Inflammation in Gastrointestinal Mucosa
}

\author{
Feriyl Bhaijee, ${ }^{1}$ Keith A. Brown, ${ }^{2}$ Billy W. Long, ${ }^{2}$ and Alexandra S. Brown ${ }^{1}$ \\ ${ }^{1}$ Department of Pathology, University of Mississippi Medical Center, 2500 North State Street, Jackson, MS 39216, USA \\ ${ }^{2}$ GI Associates \& Endoscopy Center, 1405 North State Street Suite 308, Jackson, MS 39202, USA
}

Correspondence should be addressed to Feriyl Bhaijee; fbhaijee@gmail.com

Received 8 July 2013; Accepted 11 September 2013

Academic Editor: Kenneth C. Kalunian

Copyright (c) 2013 Feriyl Bhaijee et al. This is an open access article distributed under the Creative Commons Attribution License, which permits unrestricted use, distribution, and reproduction in any medium, provided the original work is properly cited.

First described in 1998, Russell body gastritis is a rare chronic inflammatory condition characterized by abundant intramucosal polyclonal plasma cells, which contain intracytoplasmic eosinophilic globules of immunoglobulins (Russell bodies) that displace the nucleus, with an accompanying chronic inflammatory infiltrate. Russell bodies represent a cellular response to overstimulation of plasma cells, leading to the accumulation of abundant, nondegradable, condensed immunoglobulin in dilated rough endoplasmic reticulum cisternae. Russell body gastritis usually occurs in the gastric antrum, but two cases of Russell body duodenitis have been recently described. Herein, we report an unusual case of Barrett esophagus with prominent lymphoplasmacytic infiltration and Russell bodies, which expands the current spectrum of Russell body gastritis/duodenitis. Given the various anatomic locations in which Russell body gastritis may arise, we suggest that "Russell body gastroenteritis" may be a more appropriate designation for this uncommon reactive condition.

\section{Introduction}

First described in 1998 [1], Russell body gastritis (RBG) is a rare inflammatory condition characterized by abundant intramucosal polyclonal plasma cells, which contain intracytoplasmic, eosinophilic globules of immunoglobulins (Russell bodies) that displace the nucleus, with an accompanying chronic inflammatory infiltrate. It usually occurs in the gastric antrum, but two cases of Russell body duodenitis have been recently described. Herein, we report an unusual case of Barrett esophagus with prominent lymphoplasmacytic infiltration and Russell bodies, which expands the current spectrum of Russell body gastritis/duodenitis.

\section{Case Report}

A 69-year-old male with a history of Barrett esophagus $(6 \mathrm{~cm}$ length of involvement) underwent an ablation procedure, which resulted in a residual $1-1.5 \mathrm{~cm}$ band of Barrett mucosa (Figure 1) that was separated from the gastroesophageal junction by endoscopically unremarkable squamous mucosa. Two years later, biopsies from the residual band of Barrett mucosa showed intestinal metaplasia with active inflammation and numerous monomorphic cells in the lamina propria with eccentric nuclei and abundant eosinophilic cytoplasm (Figure 2). The monomorphic cells were highlighted by a periodic acid-Schiff (PAS) stain and immunohistochemical studies for CD79a, kappa, and lambda (Figures 3, 4, 5, and 6). There was no immunoreactivity with pan-cytokeratins (AE1/AE3). This immunohistochemical profile supported that these cells were polyclonal plasma cells, as seen in Russell body gastritis (RBG). The Barrett mucosa was called indefinite for dysplasia due to active inflammation.

\section{Discussion}

Russell body gastritis/duodenitis is an unusual form of chronic gastrointestinal mucosal inflammation, characterized by abundant plasma cells containing eosinophilic cytoplasmic globules. Russell bodies represent a cellular response to overstimulation of plasma cells, leading to the accumulation of abundant, nondegradable, condensed immunoglobulin in dilated rough endoplasmic reticulum cisternae [2] 


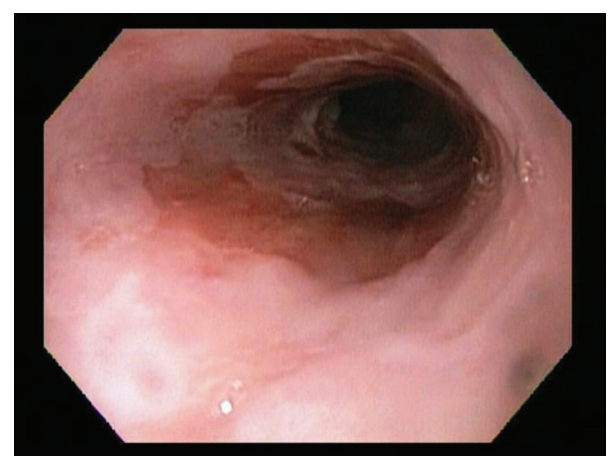

FIGURE 1: Upper endoscopy (esophagogastroduodenoscopy): a residual 1-1.5 cm band of salmon-pink Barrett mucosa separated from the gastroesophageal junction by endoscopically unremarkable squamous mucosa.

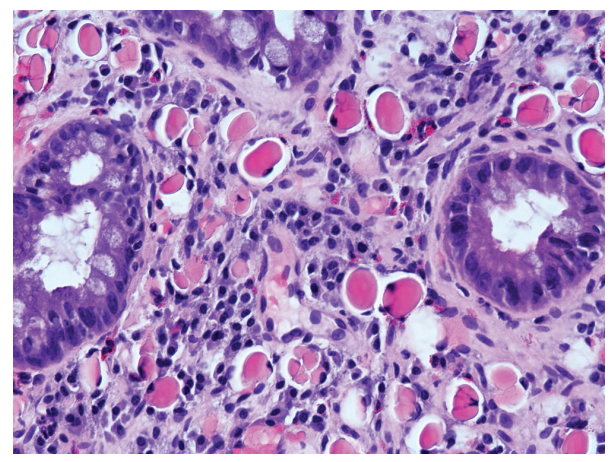

FIgURE 2: Hematoxylin and eosin, 20x. Biopsies from the Barrett mucosa showed intestinal metaplasia with active inflammation and numerous monomorphic cells in the lamina propria with eccentric nuclei and abundant eosinophilic cytoplasm.

Plasma cells filled with abundant intracytoplasmic Russell bodies are called Mott cells, which can be seen in disease states characterized by plasmacytosis and chronic inflammation, such as chronic follicular gastritis, autoimmunemediated diseases such as Hashimoto's thyroiditis and rheumatoid arthritis, and hematopoietic tumors with plasmacytic differentiation, such as MALT lymphoma, plasmacytoma, or lymphoplasmacytic lymphoma [3]. Mott cells are extremely rare in epithelial tumors. In gastrointestinal mucosal plasmacytic infiltrates, the absence of nuclear atypia, mitotic activity, lymphoepithelial lesions, and monoclonal infiltrates, favors a benign, reactive process, such as chronic inflammation.

Including our current case, there are 24 reported cases of Russell body gastritis, duodenitis, and Barrett esophagitis in the English medical literature (Table 1) [1, 3-22]. The mean age of affected patients in these reports is 61 years (range 3488 years), with a male-to-female ratio of $2.4: 1$. Most patients presented with nonspecific gastrointestinal symptoms, such as abdominal discomfort, nausea, and dyspepsia. Endoscopic features were likewise non-specific, including mucosal erythema, edema, erosion, ulceration, or, rarely, raised nodules. Biopsy specimens from all cases showed active chronic

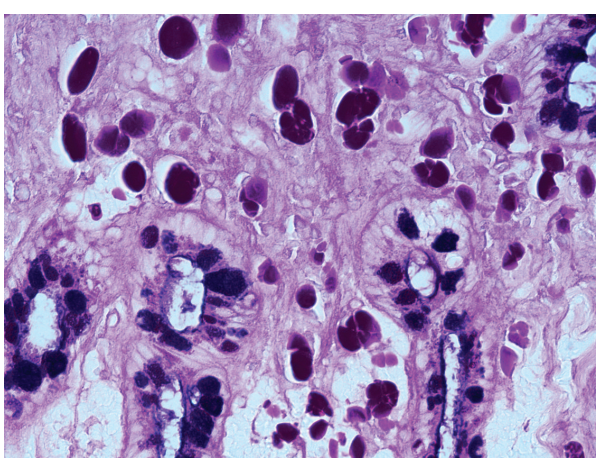

Figure 3: Periodic acid-Schiff-Alcian blue stain ( $\mathrm{pH}$ 2.5), 20x. The monomorphic cells were highlighted by a periodic acid-Schiff (PAS) stain; note the dark blue inhomogeneous staining of intracytoplasmic mucin in the intestinal-type metaplastic goblet cells, which is characteristic in Barrett mucosa.

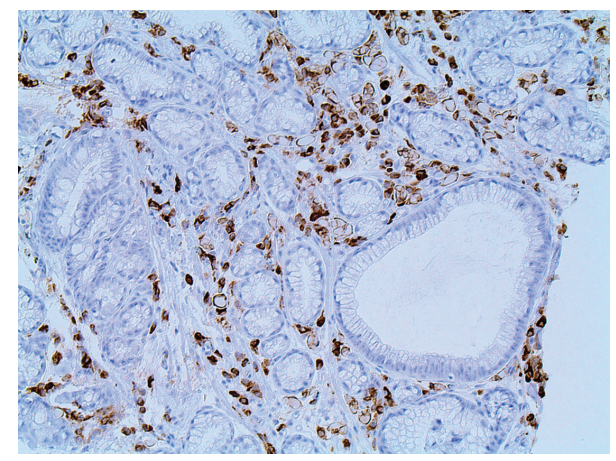

Figure 4: CD79a immunostain, 20x. The distended protein-containing cells in the lamina propria are highlighted by CD79a, a plasma cell marker.

inflammation with either focal or diffuse accumulation of plasma cells containing Russell bodies. Of the 20 gastric cases, 12 showed evidence of Helicobacter pylori infection; all 4 extragastric (duodenal and esophageal) cases were $H$. pylori negative. Other associated conditions included HIV infection $[9,11,16,20]$, ethanol abuse $[1,5]$, gastric carcinoma $[14,19]$, Barrett esophagus [22], monoclonal gammopathy of uncertain significance [8], and concurrent Hepatitis C infection and insulin-dependent diabetes mellitus [17].

While plasmacytic infiltrates are the hallmark of gastric chronic inflammation, plasma cells containing Russell bodies are rare in Helicobacter pylori-associated gastritis. It is hypothesized that chronic Helicobacter infection stimulates plasma cell-driven hyperproduction of immunoglobulins, which leads to Russell body formation and Mott cell proliferation. The highly pathogenic Helicobacter pylori genotypes vacA and cagA may also be associated with RBG [23]. The disappearance of Russell bodies following successful Helicobacter pylori eradication therapy also supports the etiopathogenic role of the organism in RBG $[1,3,7,10,11$, $13,15]$. In 2006, Stewart and Spagnola reported three cases of Helicobacter-associated gastritis with crystalline plasma cell inclusions, which may represent another morphologic 
TABLE 1: Reported cases of Russell body gastritis, duodenitis, and Barrett esophagus.

\begin{tabular}{|c|c|c|c|c|c|c|}
\hline Case & Authors & Age/sex & Location & H. pylori infection & Other conditions & Country \\
\hline 1 & Yu et al. $1987[4]$ & $65 / \mathrm{F}$ & Stomach & Unknown & Unknown & Korea \\
\hline 2 & Tazawa and Tsutsumi 1998 [1] & $53 / \mathrm{M}$ & Stomach & Yes & Ethanol abuse & Japan \\
\hline 3 & Erbersdobler et al. 2004 [5] & $83 / \mathrm{F}$ & Stomach & No & $\begin{array}{c}\text { Esophageal } \\
\text { candidiasis, ethanol } \\
\text { abuse }\end{array}$ & Germany \\
\hline 4 & Ensari et al. 2005 [6] & $70 / \mathrm{M}$ & Stomach & Yes & - & Turkey \\
\hline 5 & Paik et al. 2006 [7] & $47 / \mathrm{F}$ & Stomach & Yes & - & Korea \\
\hline 6 & Paik et al. 2006 [7] & $53 / \mathrm{F}$ & Stomach & Yes & - & Korea \\
\hline 7 & Wolkersdörfer et al. 2006 [8] & $54 / \mathrm{M}$ & Stomach & Yes & MGUS & Germany \\
\hline 8 & Drut and Olenchuk 2006 [9] & $34 / \mathrm{M}$ & Stomach & No & $\mathrm{HIV}+$ & Argentina \\
\hline 9 & Pizzolitto et al. 2007 [10] & $60 / \mathrm{F}$ & Stomach & Yes & - & Italy \\
\hline 10 & Eum et al. 2007 [3] & $48 / \mathrm{M}$ & Stomach & Yes & Colonic polyps & Korea \\
\hline 11 & Licci et al. 2009 [11] & $59 / \mathrm{M}$ & Stomach & Yes & $\mathrm{HIV}+$ & Italy \\
\hline 12 & Habib et al. 2010 [12] & $75 / \mathrm{M}$ & Stomach & No & $\begin{array}{l}\text { Renal failure, } \\
\text { dyslipidemia, ethanol } \\
\text { abuse, and prior } \\
\text { rhabdomyolysis }\end{array}$ & USA \\
\hline 13 & Del Gobbo et al. 2011 [13] & $78 / \mathrm{F}$ & Stomach & No & - & Italy \\
\hline 14 & Wolf et al. 2011 [14] & $67 / \mathrm{M}$ & Stomach & Yes & $\begin{array}{l}\text { Signet ring cell } \\
\text { carcinoma }\end{array}$ & Austria \\
\hline 15 & Yoon et al. 2012 [15] & $57 / \mathrm{M}$ & Stomach & Yes & $\begin{array}{c}\text { Gastric \& colonic } \\
\text { polyps }\end{array}$ & Korea \\
\hline 16 & Yoon et al. 2012 [15] & $43 / \mathrm{M}$ & Stomach & Yes & - & Korea \\
\hline 17 & Bhalla et al. 2012 [16] & $82 / \mathrm{M}$ & Stomach & No & HIV+ & USA \\
\hline 18 & Coyne and Azadeh 2012 [17] & $49 / \mathrm{M}$ & Stomach & No & Hepatitis C+, IDDM & UK \\
\hline 19 & Karabagli and Gokturk 2012 [18] & $60 / \mathrm{M}$ & Stomach & Yes & - & Turkey \\
\hline 20 & Choi et al. 2012 [19] & $55 / \mathrm{M}$ & Stomach & Yes & $\begin{array}{c}\text { Gastric } \\
\text { adenocarcinoma }\end{array}$ & Korea \\
\hline 21 & Savage et al. 2011 [20] & $55 / \mathrm{M}$ & Duodenum & No & HIV+, lymphoma & USA \\
\hline 22 & Mondolfi et al. 2012 [21] & $69 / \mathrm{F}$ & Duodenum & No & $\begin{array}{l}\text { Crohn's disease, } \\
\text { cirrhosis, rheumatoid } \\
\text { arthritis, and obesity }\end{array}$ & USA \\
\hline 23 & Rubio 2005 [22] & $88 / \mathrm{M}$ & Esophagus & No & Barrett esophagus & Sweden \\
\hline 24 & Bhaijee et al. & $71 / \mathrm{M}$ & Esophagus & No & Barrett esophagus & USA \\
\hline
\end{tabular}

manifestation of immunoglobulin accumulation in response to chronic gastritis [24].

While RGB is usually a benign incidental finding associated with Helicobacter infection $[1,6,11]$, it has also been described in association with gastric tubular [19] and signet ring cell [14] adenocarcinoma. Russell bodies are actually more frequently seen in normal tissues adjacent to malignant processes compared to benign conditions, which suggests a possible association between malignancy and Russell body formation [25]. Coexistence of gastric carcinoma and RBG is not entirely unexpected, given the frequent association between RBG and chronic Helicobacter infection-an established risk factor for gastric cancer.

In 2010, Shinozaki et al. [26] reported two cases of lymphoepithelioma-type, EBV-associated gastric carcinoma with extensive lymphoplasmacytic infiltration and prominent Mott cells [26]. EBER in situ hybridization highlighted the tumor cells obscured by the Mott cell proliferations, and the authors postulated that aberrant chemokine expression in the EBV-driven tumors led to plasma cell activation and subsequent Russell body formation and Mott cell proliferation. Although both cases also showed evidence of $H$. pylori infection, the Mott cell proliferations were confined to the mucosa involved by the tumors and were not seen in the background mucosa; thus, RBG was excluded.

Russell body duodenitis has recently been reported in two patients: a 55-year-old HIV-infected male [20] and a 69-year-old female [21] with autoimmune disease. In both cases, the Russell body infiltrates and chronic inflammation occurred in areas of duodenal gastric metaplasia and, notably, in the absence of demonstrable Helicobacter infection. In this setting, Russell body duodenitis may represent either the residual sequela of healed or partiallytreated gastric Helicobacter infection or an abnormal response to disordered 


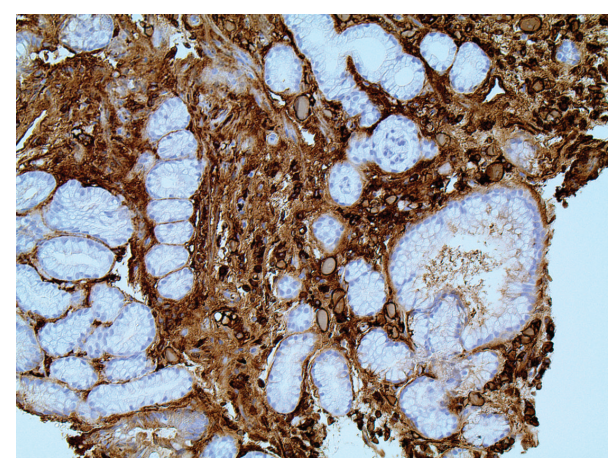

FIGURE 5: Kappa light chain immunostain, 20x. The Russell bodyladen plasma cells show both kappa and lambda (i.e., polyclonal) immunoglobulin expression.

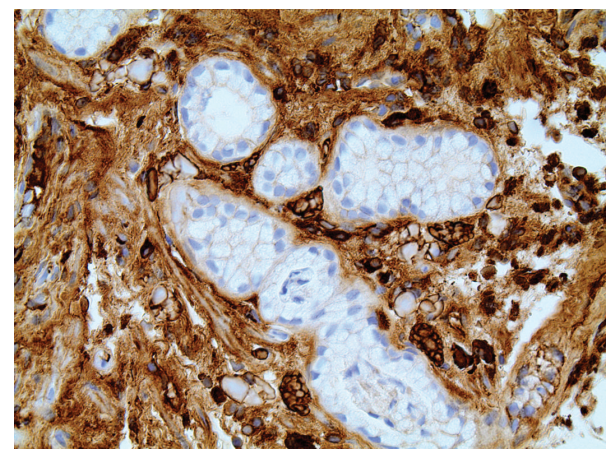

FIgURE 6: Lambda light chain immunostain, 40x. The Russell bodyladen plasma cells show both kappa and lambda (i.e., polyclonal) immunoglobulin expression.

systemic immune responses. In 2005, Rubio described Mott cells in Barrett esophagus [22]. To our knowledge, the current case is the second reported case of RBG in Barrett esophagus. Regardless of anatomic location, it is likely that chronic inflammation causes aberrant chemokine expression, resulting in overstimulation of plasma cells, excessive immunoglobulin production, and subsequent Russell body formation.

RBG represents a potential diagnostic pitfall because the distended plasma cells may be mistaken for signet ring tumor cells [4]. The plasma cells in RBG, however, lack nuclear atypia, mucicarmine, and cytokeratin expression. The periodic acid-Schiff reaction may help identify Russell bodies by conferring a dense, glassy stain to intracytoplasmic immunoglobulins. Plasma cell markers, such as CD138 and CD79a, and concomitant kappa and lambda light chain expression will demonstrate the polyclonal nature of the plasma cell infiltrate. Associated gastric carcinoma and infectious agents, such as Helicobacter and Candida, may alter patient management and clinical outcome and therefore should be excluded by ancillary studies.

The differential diagnosis for plasma cell infiltrates in the lamina propria of the luminal gastrointestinal tract including plasma cell neoplasms, such as plasmacytoma and mucosaassociated lymphoid tissue (MALT) lymphoma with plasmacytic differentiation. Benign Mott cell proliferations can be distinguished from hematopoietic malignancies by the absence of cellular atypia, mitotic activity, and monoclonality. Immunohistochemistry, in situ hybridization, and PCR for immunoglobulin heavy chain rearrangements aid in the evaluation of clonality.

The management of RBG involves Helicobacter eradication therapy and exclusion of associated conditions, including other infectious agents and gastric carcinoma.

In conclusion, we report the second case of Barrett esophagus with prominent lymphoplasmacytic infiltration and Russell bodies, which expands the current spectrum of Russell body gastritis/duodenitis. Given the various anatomic locations in which Russell body gastritis may arise, we suggest that "Russell body gastroenteritis" may be a more appropriate designation for this uncommon reactive condition.

\section{References}

[1] K. Tazawa and Y. Tsutsumi, "Localized accumulation of Russell body-containing plasma cells in gastric mucosa with Helicobacter pylori infection: 'Russell body gastritis,' Pathology International, vol. 48, no. 3, pp. 242-244, 1998.

[2] S. M. Hsu, P. L. Hsu, P. N. McMillan, and H. Fanger, "Russell bodies: a light and electron microscopic immunoperoxidase study," American Journal of Clinical Pathology, vol. 77, no. 1, pp. 26-31, 1982.

[3] S. W. Eum, J. H. Lee, K. Y. Kim et al., "A case of Russell body gastritis associated with Helicobacter pylori infection," Korean Journal of Gastrointestinal Endoscopy, vol. 35, pp. 181-185, 2007.

[4] E. S. Yu, Y. I. Kim, C. W. Kim, and W. H. Kim, "Russell body: containing plasma cell aggregations mimicking signet ring cell carcinoma of the stomach," Korean Journal of Gastrointestinal Endoscopy, vol. 7, pp. 39-41, 1987.

[5] A. Erbersdobler, S. Petri, and G. Lock, "Russell body gastritis: an unusual, tumor-like lesion of the gastric mucosa," Archives of Pathology and Laboratory Medicine, vol. 128, no. 8, pp. 915-917, 2004.

[6] A. Ensari, B. Savas, A. O. Heper, I. Kuzu, and R. Idilman, "An unusual presentation of helicobacter pylori infection: so-called "Russell body gastritis"', Virchows Archiv, vol. 446, no. 4, pp. 463-466, 2005.

[7] S. Paik, S.-H. Kim, J.-H. Kim, W. I. Yang, and Y. C. Lee, "Russell body gastritis associated with Helicobacter pylori infection: a case report," Journal of Clinical Pathology, vol. 59, no. 12, pp. 1316-1319, 2006.

[8] G. W. Wolkersdörfer, M. Haase, A. Morgner, G. Baretton, and S. Miehlke, "Monoclonal gammopathy of undetermined significance and Russell body formation in Helicobacter pylori gastritis," Helicobacter, vol. 11, no. 5, pp. 506-510, 2006.

[9] R. Drut and A. B. Olenchuk, "Russell body gastritis in an HIVpositive patient," International Journal of Surgical Pathology, vol. 14, no. 2, pp. 141-142, 2006.

[10] S. Pizzolitto, D. Camilot, G. DeMaglio, and G. Falconieri, "Russell body gastritis: expanding the spectrum of Helicobacter pylori-related diseases?" Pathology Research and Practice, vol. 203, no. 6, pp. 457-460, 2007.

[11] S. Licci, P. Sette, F. Del Normo, S. Ciarletti, A. Antlnort, and L. Morellt, "Russell body gastritis associated with helicobacter pylori Infection in an HIV-positive patient: case report and review of the literature," Zeitschrift fur Gastroenterologie, vol. 47, no. 4, pp. 357-360, 2009. 
[12] C. Habib, D. L. Gang, R. Ghaoui, and L. Pantanowitz, "Russell body gastritis," American Journal of Hematology, vol. 85, no. 12, pp. 951-952, 2010.

[13] A. del Gobbo, L. Elli, P. Braidotti, F. di Nuovo, S. Bosari, and S. Romagnoli, "Helicobacter pylori-negative russell body gastritis: case report," World Journal of Gastroenterology, vol. 17, no. 9, pp. 1234-1236, 2011.

[14] E.-M. Wolf, K. Mrak, J. Tschmelitsch, and C. Langner, "Signet ring cell cancer in a patient with Russell body gastritis-a possible diagnostic pitfall," Histopathology, vol. 58, no. 7, pp. 11781180, 2011.

[15] J. B. Yoon, T. Y. Lee, J. S. Lee et al., "Two cases of Russell body gastritis treated by Helicobacter pylori eradication," Clinical Endoscopy, vol. 45, pp. 412-416, 2012.

[16] A. Bhalla, D. Mosteanu, S. Gorelick, and Hani-el-Fanek, "Russell body gastritis in an HIV positive patient: case report and review of literature," Connecticut Medicine, vol. 76, no. 5, pp. 261-265, 2012.

[17] J. D. Coyne and B. Azadeh, "Russell body gastritis: a case report," International Journal of Surgical Pathology, vol. 20, no. 1, pp. 6970, 2012.

[18] P. Karabagli and H. S. Gokturk, "Russell body gastritis: case report and review of the literature," Journal of Gastrointestinal and Liver Diseases, vol. 21, no. 1, pp. 97-100, 2012.

[19] J. Choi, H. E. Lee, S. Byeon, K. H. Nam, M. A. Kim, and W. H. Kim, "Russell body gastritis presented as a colliding lesion with a gastric adenocarcinoma: a case report," Basic \& Applied Pathology, vol. 5, pp. 54-57, 2012.

[20] N. M. Savage, T. Fortson, M. Schubert, S. Chamberlain, J. Lee, and P. Ramalingam, "Isolated russell body duodenitis," Digestive Diseases and Sciences, vol. 56, no. 7, pp. 2202-2204, 2011.

[21] A. P. Mondolfi, M. Samuel, J. Kikhney et al., "Russell body duodenitis: a histopathological and molecular approach to a rare clinical entity," Pathology, Research and Practice, vol. 208, pp. 415-419, 2012.

[22] C. A. Rubio, "Mott cell (Russell bodies) Barrett's oesophagitis," In Vivo, vol. 19, no. 6, pp. 1097-1100, 2005.

[23] A. Soltermann, S. Koetzer, F. Eigenmann, and P. Komminoth, "Correlation of Helicobacter pylori virulence genotypes vacA and cagA with histological parameters of gastritis and patient's age," Modern Pathology, vol. 20, no. 8, pp. 878-883, 2007.

[24] C. J. R. Stewart and D. V. Spagnolo, "Crystalline plasma cell inclusions in helicobacter-associated gastritis," Journal of Clinical Pathology, vol. 59, no. 8, pp. 851-854, 2006.

[25] A. Johansen and B. Sikjar, "The diagnostic significance of Russell bodies in endoscopic gastric biopsies," Acta Pathologica et Microbiologica Scandinavica A, vol. 85, no. 2, pp. 245-250, 1977.

[26] A. Shinozaki, T. Ushiku, and M. Fukayama, "Prominent Mott cell proliferation in Epstein-Barr virus-associated gastric carcinoma," Human Pathology, vol. 41, no. 1, pp. 134-138, 2010. 


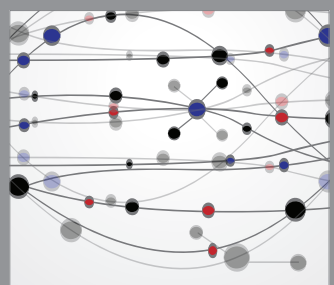

The Scientific World Journal
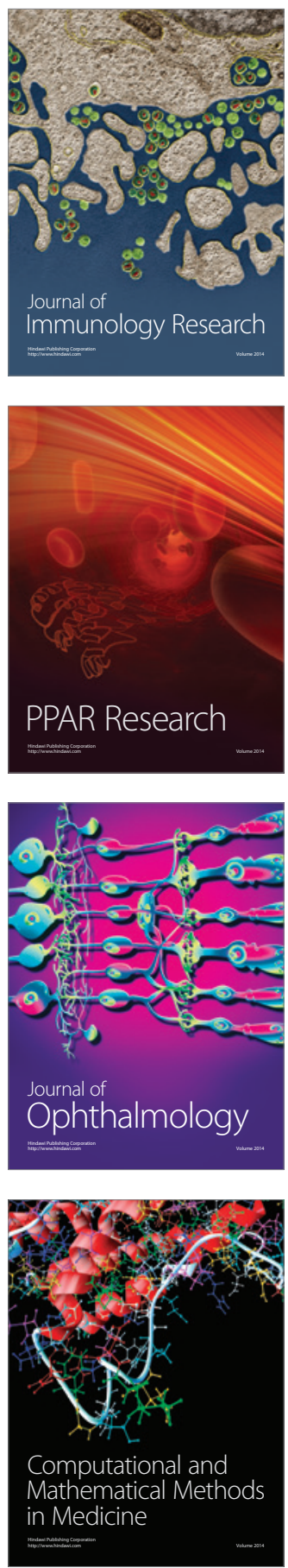

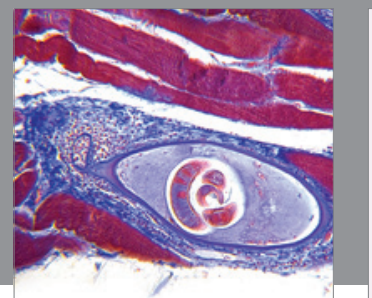

Gastroenterology

Research and Practice
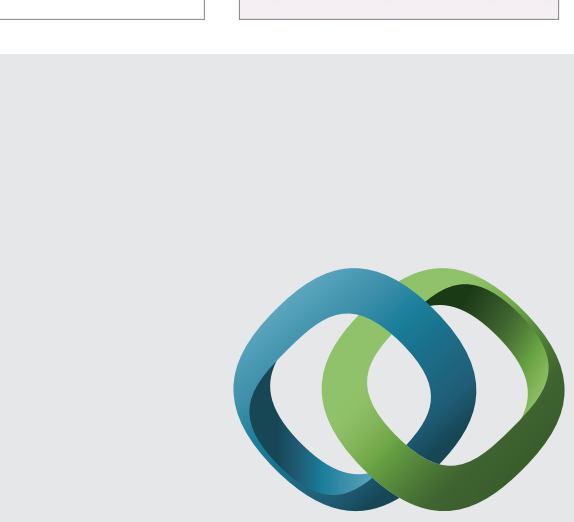

\section{Hindawi}

Submit your manuscripts at

http://www.hindawi.com
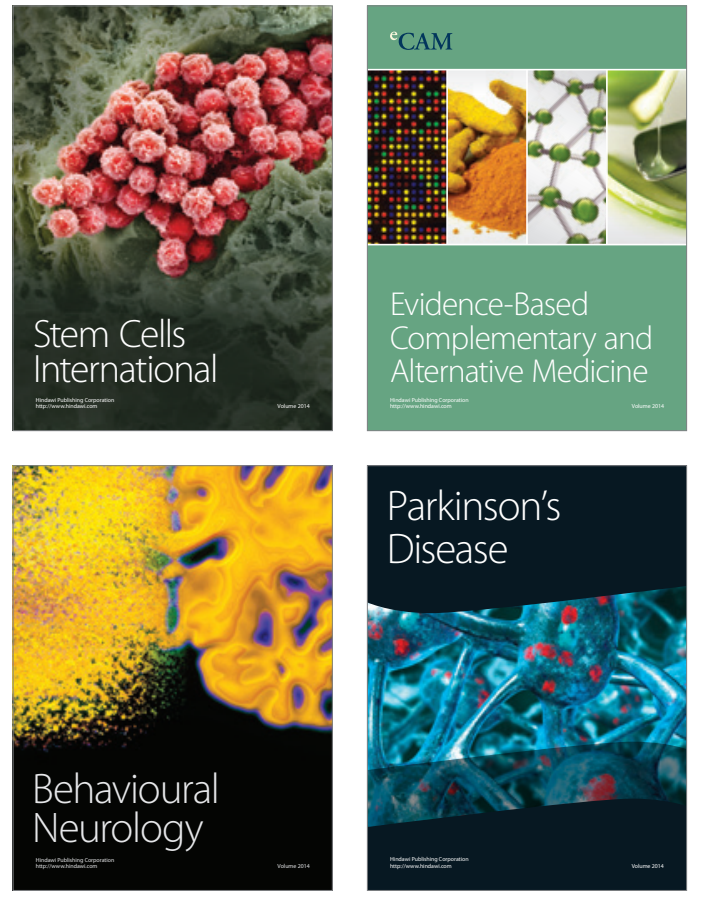
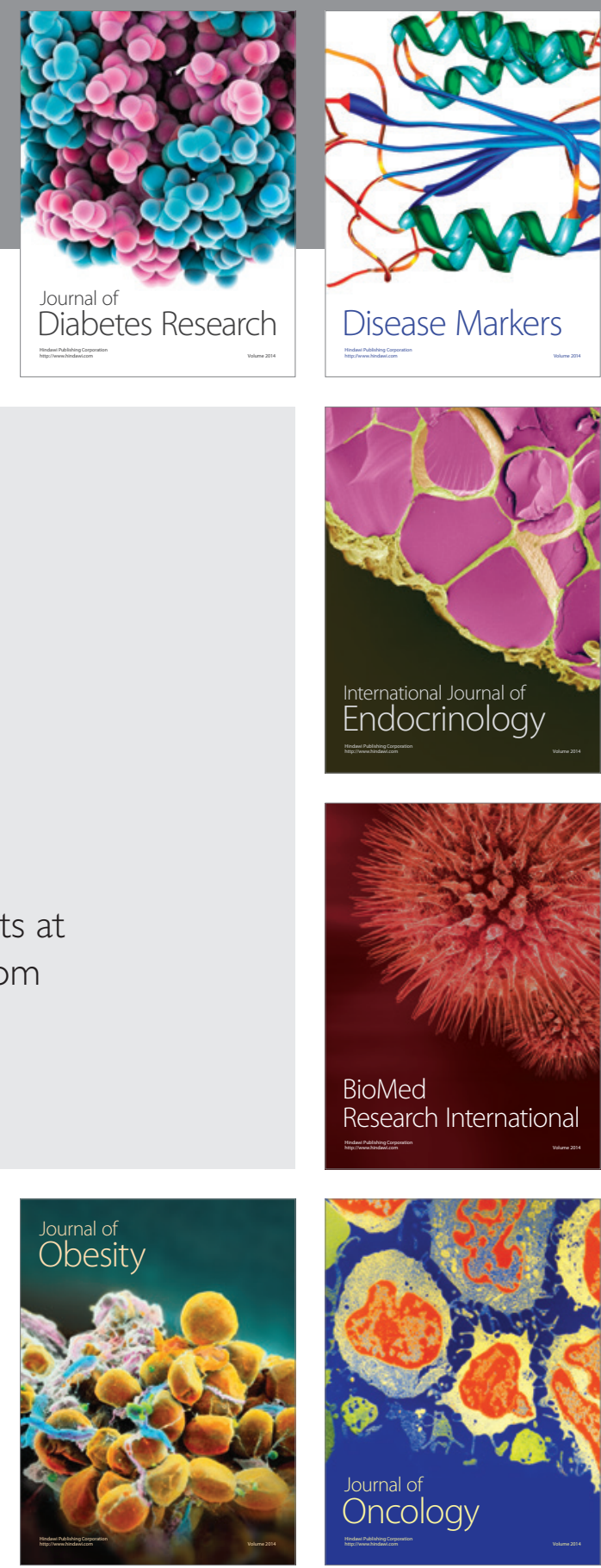

Disease Markers
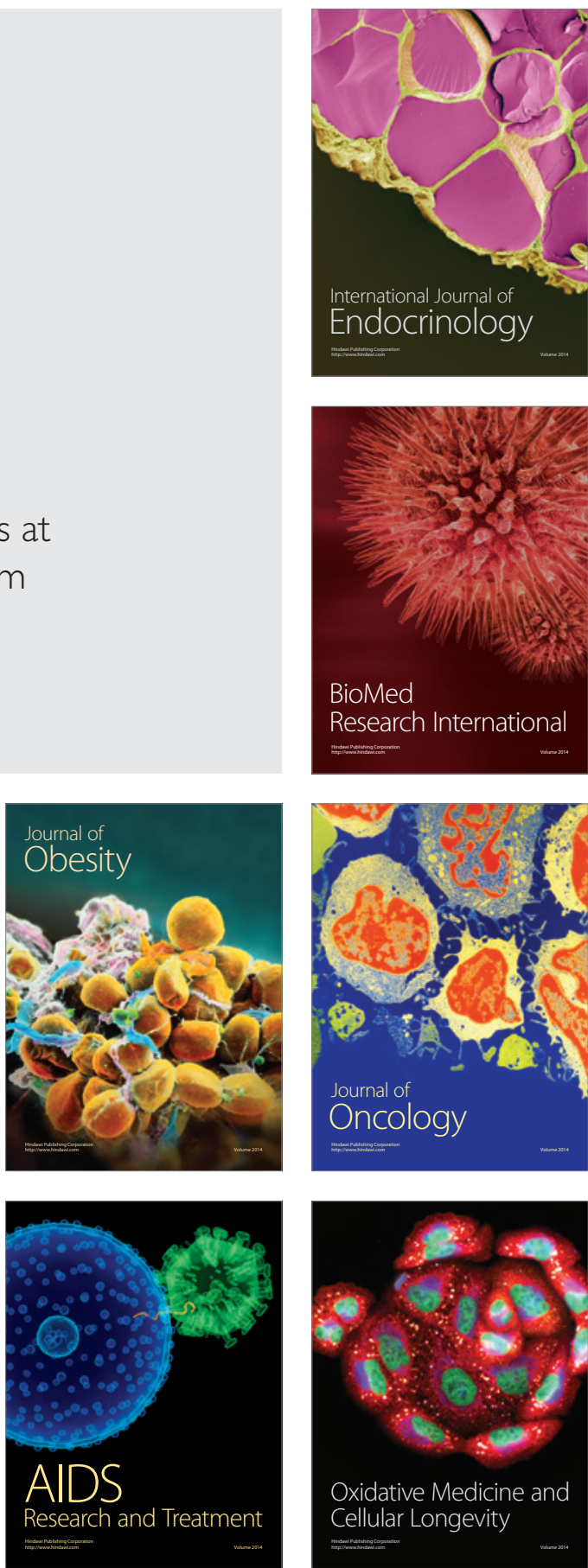